SpringerBriefs in Religious Studies 
More information about this series at http://www.springer.com/series/13200 
Terence Lovat · Robert Crotty

\section{Reconciling Islam, Christianity and Judaism}

Islam's Special Role in Restoring

Convivencia

Springer 
Terence Lovat

The University of Newcastle

Newcastle, NSW

Australia

and

University of Oxford

Oxford

UK
Robert Crotty

University of South Australia

Adelaide, SA

Australia

\section{SpringerBriefs in Religious Studies}

ISBN 978-3-319-15547-0

ISBN 978-3-319-15548-7 (eBook)

DOI 10.1007/978-3-319-15548-7

Library of Congress Control Number: 2015932238

Springer Cham Heidelberg New York Dordrecht London

(C) The Author(s) 2015

This work is subject to copyright. All rights are reserved by the Publisher, whether the whole or part of the material is concerned, specifically the rights of translation, reprinting, reuse of illustrations, recitation, broadcasting, reproduction on microfilms or in any other physical way, and transmission or information storage and retrieval, electronic adaptation, computer software, or by similar or dissimilar methodology now known or hereafter developed.

The use of general descriptive names, registered names, trademarks, service marks, etc. in this publication does not imply, even in the absence of a specific statement, that such names are exempt from the relevant protective laws and regulations and therefore free for general use.

The publisher, the authors and the editors are safe to assume that the advice and information in this book are believed to be true and accurate at the date of publication. Neither the publisher nor the authors or the editors give a warranty, express or implied, with respect to the material contained herein or for any errors or omissions that may have been made.

Printed on acid-free paper

Springer International Publishing AG Switzerland is part of Springer Science+Business Media (www.springer.com) 


\section{Preface}

We devote this book to understanding better the fractures so evident in the Abrahamic religions (Islam, Christianity and Judaism) today, such that these fractures have come to affect world order and threaten global wellbeing. We do so in order to instil greater understanding as to the reasons for the fractures and the possibility of those religions living in harmony despite them, a harmony that would inevitably spill over to a more stable world order. We contend that history shows they can live well together, as in the example of medieval Convivencia (literally 'harmonious co-existence'), when Muslims, Christians and Jews lived together, relatively peacefully and cooperatively, between the eighth and fifteenth centuries, mainly in Southern (Moorish) Spain. We also contend that, as was the case then, the role of Islam in forging this positive coexistence remains a crucial one. We would hope that despite limiting ourselves to the Abrahamic religions, as vital as they are to today's world order, the principles could be seen as applying to a host of other inter-religious relations.

Trible and Russell proffer that

... understanding problems and opportunities of the past and present among Jews, Christians and Muslims, as well as envisioning a different future, resides more in studying the women Hagar and Sarah than in stressing the putative unity located in Abraham (2006, p. 1).

In fact, in this book we intend to focus on Abraham (Ibrahim in Arabic), partly for the 'putative unity' but also for the fractures and disputations that are apparent in the stories of Hagar (Hajar), Sarah (both Hebrew and Arabic) and their respective children-Ishmael (Ishma'il) and Isaac (Ishaq). ${ }^{1}$ We do so with a similar sense of purpose to that expressed by Trible and Russell, namely to facilitate awareness

\footnotetext{
${ }^{1}$ We intend, in so far as it is possible, to use the common Hebrew-Western name for the characters when dealing with a Jewish or Christian context and the Arabic name when dealing with an Islamic context. Likewise, Jesus (Issa) will change with the context. At times, contexts will overlap and a judicious choice will be made whether to include both forms of the name or select one only. The authors have no personal preference.
} 
of the differences in the three Abrahamic religions' understanding of these characters so that we might lay the grounds for what we choose to describe as renewed Convivencia. We begin with a few words of clarification about this central notion.

Perhaps it would be more accurate to say that we are attempting to re-lay the grounds for Convivencia, because, as suggested above, the word captures a moment in past time when Jews, Christians and Muslims appeared to have achieved a mutual accommodation, invariably within Muslim worlds, whereby their differences mattered less than their commonly understood allegiance to monotheism and the true God, variously titled, that they shared. So, these grounds were once laid in a tangible way, in real time, recorded by historians using empirical method. This, in other words, is not fantasy or even overly wishful thinking and this lesson from history is an important one for today. Re-laying the grounds for such an accommodation seems to us to be a particularly urgent task in the interests of contemporary global stability and wellbeing, as well as Muslim, Christian and Jewish mutual understanding and, for each of them, greater self-understanding.

Furthermore, we believe that one of the keys with most potential for unlocking the door that is currently closed to Convivencia is to be found in the sacred textual characters mentioned above, in part shared, yet in part disputed by the three religions in question. While we focus on the three different textual accounts of these characters, we believe that, especially for a Western audience, giving a public voice to the Muslim account is a particularly important thing to do. Why? Certainly not because we wish to place the burden of Convivencia on Islam alone or to imply that the other two sibling traditions have no soul-searching to do about the roles they have played in the breakdown of Convivencia. On the contrary!

In fact, we focus on Islam for two main reasons: The first reason relates to the widely held perception by the Muslim world that the so-called 'Western World' (which increasingly Muslim populations share) is dismissive of, if not hostile to, Muslim claims over the Abrahamic heritage and the ensuing covenant (agreement) by God to establish a godly community under Abraham's patronage. This dismissal of what are seen by generations of Muslims as legitimate claims has been central to the rapid and effective way in which radical and often hostile forms of Islamism (connoting the more radical forms of Islam) have been stirred into active hatred of 'the Western World' with consequent revilement and violence. Scholarly dialogue and debate, as well as an enhanced understanding by wider populations of the West about Islam and its most precious claims, might play some part in weakening the hold that such radical Islamist forms have over increasing Muslim populations. In that respect, we focus on Islam for the education and edification of non-Muslims and Muslims who do not know about the issue. The West does not always understand this matter; perhaps some in the Muslim world do not understand it.

Second, it is an undeniable fact that Islam played an especially powerful leadership role in those societies where Convivencia was realised, most clearly in medieval Moorish Spain. It was the advent of the radical monotheism of Islam, proffering a Universal God rather than a selective one, and supported by a radical social reform agenda sitting at the heart of its purpose and self-understanding, that impelled much of the reality of Convivencia. We will also contend that part of 
Islam's leadership role in establishing and maintaining Convivencia is owing to the fact that it alone of the three religions possesses a theology that incorporates and understands the role of the other two religions. By the logic of history, we are entitled therefore to suggest that the role of Islam in establishing a new era of Convivencia is deserving of special attention.

In making the case about Convivencia and Islam's special role, we need to be clear about our methodological procedure. We begin with a theory of religion and then make application of the theory to the Abrahamic traditions. We then outline the three accounts of the above sacred textual characters, what we describe broadly as the 'Abrahamic (Ibrahimic) Story', looking for points of commonality and those of difference. We turn then to exploring the latter for clues about the emanation of conflict and attempt an appraisal of the extent to which the clues for this actually lie in the different accounts and the disputations thereof. Next, we turn to the instances of historical Convivencia, identifying the various factors and features that characterized them and the ways in which the different accounts were accommodated and served as glue for these multi-faith societies. As part of this, we note the crucial role played by the Muslim portion of the relevant populations, whether they were holding political power at the time or not. Finally, we turn to issues confronting us in the present day and explore ways in which Convivencia might be recovered through education for greater understanding and commitment to work for the common good, including the common Abrahamic good.

So, the major methodological strategy begins with a generalized theory of religion. The theory will demonstrate that we characterize religious traditions as options that can learn to live together in harmony. That is the theme of this book, albeit understood that it is an arguable one that will need to be justified and reviewed. That religious traditions are options is also the basis for the ethical proposition that the book makes - namely that it is incumbent on all religious traditions to learn to live in harmony. This we believe applies to all religions but especially to the so-called 'Abrahamic religions' which, on the one hand, have such a common heritage and, on the other hand, tend to be at the centre of arguably the world's most persistent and dangerous conflicts, including most centrally the seemingly intractable disputation over the holy city of Jerusalem and its allied issues.

As suggested, it will be maintained that the three Abrahamic religions-Islam, Christianity and Judaism - are best regarded as religious options that have much in common in their structure and beliefs and which have enjoyed harmonious relations in the past and on which a particular ethical obligation lies to find harmony in today's world.

It must be made clear from the outset that it will be argued that none of the three Abrahamic religions is built on historical absolutes; it will be demonstrated that they are built on sacred Stories that relate a religious tradition in a particular way. In this context, the sacred mega-Story that contains the particular stories of Abraham (Ibrahim), Sarah, Hagar (Hajar), Isaac (Ishaq), Ishmael (Ishma'il), a mega-Story shared in some ways by these three religions, has been identified as being a key factor in the religious tradition of each of the three religions. This common heritage 
is the very reason for their identification as belonging to the one Abrahamic religious tradition, although it has to be said that this is a notion that pertains more sharply to a Muslim perspective than a Christian or Jewish one. This is yet another reason that Islam was so important to Convivencia of the past and is considered by us to be as important to any hope of recovering Convivencia in our own time.

As much as this sacred mega-Story is held in common, it is nonetheless related in a significantly different way in each of the three religions. This point will be elaborated later but, for the moment, the following (disputed) summary of the outline of the Story may be helpful:

\begin{abstract}
Abraham and Sarah are Ancestors who travel under divine guidance from the East to a new land. They settle and are promised possession of the land by God. Succession becomes problematic however because Sarah is unable to conceive. Abraham/Ibrahim takes another partner, Hagar/Hajar, and Ishmael/Ishma'il is born as his firstborn son. Subsequently, Sarah conceives by divine intervention and Isaac/Ishaq is born as the son of the principal wife. Is he to be the successor and will the divine promises be renewed through him? The answer depends on the version. While he is still a youth, God orders Abraham/Ibrahim to sacrifice 'him' (Ishaq or Ishma'il depending on the version) on an altar. Abraham is obedient but, at the last moment, the sacrifice is halted by a divine messenger. Ishaq/Isaac/Ishma'il is not actually sacrificed.
\end{abstract}

It will be shown that, in the Judaism version, the narrative began as a foundation Story indicating ownership of land and later developed into a significant myth of martyrdom. Initially, Abraham was depicted as the Father of Israel and the Friend of God. He was promised a specific tract of land and this land would be handed on to his son and successor, Isaac. Isaac represented those who laid claim to the land at that time. At a later date in the transmission history of the Story, Isaac was seen as a martyr (even though he was not actually sacrificed), and he became the symbol of the true Jew who was willing to give himself for the sake of humanity.

Subsequently, in the later Christian version of the Story, Abraham became the religious epitome of faithfulness to God. Then, the Abraham figure was identified as a God-figure and Abraham's son, Isaac, became the prototype of Jesus who was sacrificed on the cross on Calvary, whereby he actually gave himself for the sake of humanity.

In the Islamic version, Ibrahim was identified as the Friend of God because he was the first of the prophets to apprehend the monotheism of Allah. He and his righteous son (both Ishma'il and Ishaq are declared righteous, but priority is always given to Ishma'il) established the foundation shrine of Allah, the Ka'aba in Mecca, and the son became the successor to Ibrahim as the Friend of God. In later Islamic tradition, the identification of the righteous son was more definitely accorded to Ishma'il who, together with his mother, Hajar, ${ }^{2}$ are buried near the site of the $K a$ 'aba, clearly giving their heritage priority in the tradition (understood as the covenantal tradition) over that of Sarah and Ishaq.

\footnotetext{
2 The material that will follow on Hagar/Hajar has been adapted from Crotty (2012).
} 
The sacred Story, with these discrete and significant variations in the traditions, became important to all three faiths. The importance of the Story was highlighted by it being inserted into the ongoing ritual life of the three religions. From the third century CE, Jews read the Hebrew text of the near-sacrifice of Isaac on Rosh ha-Shanah, the Jewish New Year celebration, while Christians had an insert made into their Eucharistic liturgy about the same time, asking that their sacrifice be accepted in the same way as was that 'of our patriarch, Abraham', thus identifying the Eucharistic ritual with a sacrifice. This latter reference overlooks the fact that, in all the traditions, there was no actual sacrifice of Isaac, only the command to carry out the sacrifice of the son and an expression of willingness to do so. Meanwhile, in Islam, the frantic search by Hajar for water to give to her son, Ishma'il, became a ritual part of the Islamic pilgrimage rite.

This book intends to discuss the legitimacy of these variant forms of the sacred Story about Abraham/Ibrahim, Isaac/Ishaq and Ishmael/Ishma'il—Jewish, Christian and Islamic - and to decide to what extent and in what way the Story is closely connected with the relevant religious tradition as it has been handed down to today. The three versions will not be presumed to be historical texts and will not be assessed on the basis of historicity. They will in the first instance be treated as sacred Stories, more akin to poetry and drama than history. This study will be carried out in the manner of literary criticism, attempting to uncover the meanings involved in the texts.

So we turn to the structure of the book. There are four discrete parts. The first part contains an introduction to common and disputed features of the Abrahamic religions and a related theoretical statement dealing with certain attitudes towards religion, religious phenomena and the constituencies that share religious traditions. These matters will be covered with an eye to the question of religious pluralism and religious toleration.

A second part will then analyse the texts of the three religions, with especial focus on their central sacred Stories, exploring any commonalities as well as important differences and disputed interpretations.

For reasons specified above, a third part of the book will pay particular attention to Islamic and Islamist scholarship and claims pertaining to this central sacred Story because, in our view, this is the least understood (or even acknowledged) account in the Western world and it is this lack of understanding and accommodation that has played so effectively into the hands of radical Islamist discourse.

A fourth part of the book will deal with a historical study. Late Medieval Mediterranean (particularly Spanish) history shows that, prior to the fifteenth century at least, it was possible for some historical communities to accept a nonhistorical and inclusive approach to sacred Story. People could live in harmony with the 'Other' who had a different form of a sacred Story. Furthermore, some people were capable of changing their own sacred Story and adapting it to new circumstances. This harmony always required a delicate balance, and coexistence needed to be shored up by political and religious authority and protected by economic stability, as will be explained. This is all part of what has been called (in Spain at least, and among academics) Convivencia. 
Only when political forces ceded from harmonious relations with the Other and wanted to break down any semblance of coexistence (as eventually happened in fifteenth century Spain) was a dangerous 'religious sleeper' (extra ecclesiam nulla salus - literally 'no salvation outside the church') within the Christian tradition re-activated and, at once, Convivencia came to an end. Furthermore, the religious sleeper, an innocuous doctrinal statement that can subsequently be interpreted in an extremely different way, is not exclusive to Christianity. The same phenomenon lies deeply within the other two religions as well, and equally they have been activated at times in human history, including in our own time, to the detriment of the cultural and political harmony connoted by Convivencia.

Is it possible once more to find and activate the principle of Convivencia, of harmonious coexistence, in the same way that it was experienced throughout a long period of Mediterranean history? This study concludes that indeed such a goal is possible. There are significant commonalities to be found in the historical sequence of a number of coexisting principalities living in peace and harmony during the Late Medieval period. The reformulation of a state of harmonious coexistence would require, however, that the three religions, in the first place, eschew historical claims (the very basis of exclusivism and intolerance) and return to an acknowledgement of the fluidity of sacred Story. This would not be to the detriment of the sacred Story; it would simply be a restatement of its true purpose. This reformulation would, furthermore, require the three religions to recognise the dangerous sleepers that each of them carries in its religious baggage and which, in modern times and in different guises, has been activated to the detriment of themselves, the wider Abrahamic legacy and, in ways beyond imagination until recently, to the secure survival of the human community. For each of the three Abrahamic religions, acknowledgements of this kind would be painful but necessary.

The finale of this book is that only in this way could harmonious coexistence between the Abrahamic religions be realised in the twenty-first century. If Convivencia is not feasible with these three religions, given their commonalities, then little hope could be held for any wider religious toleration. Hope is not based on a Platonic illusion; hope is based on the real situation of religion, seen in its full theoretical expanse.

We hold some hope that the book might facilitate the promotion of tolerance and the re-finding of a form of Convivencia.

Newcastle, Oxford, 2015

Terence Lovat

Adelaide

Robert Crotty 


\section{Contents}

Part I The Abrahamic Religions (Islam, Christianity and Judaism) and a Theory of Religion

1 An Introduction to the Abrahamic Religions . . . . . . . . . . 3

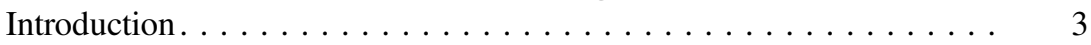

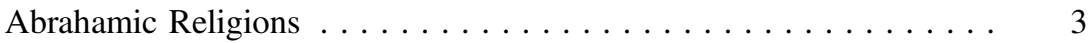

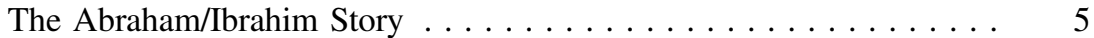

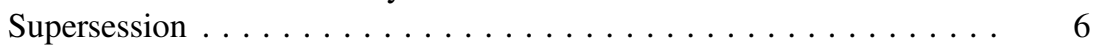

The Uneven Issue of the Enlightenment $\ldots \ldots \ldots \ldots \ldots \ldots \ldots$

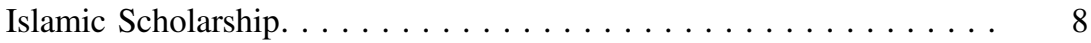

2 A Theory of Religion and Being Religious . . . . . . . . . . . . 11

Introduction. . . . . . . . . . . . . . . . . . . . . 11

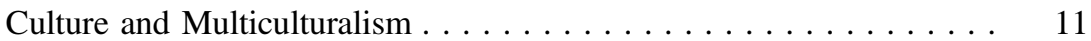

Attitudes to Everyday Culture . . . . . . . . . . . . . . . . 13

Religion and Religious Pluralism . . . . . . . . . . . . . . . . . . 15

Attitudes to Religious Culture . . . . . . . . . . . . . . . 18

Religious Pluralism. . . . . . . . . . . . . . . . . . . . . 19

Ethnocentrism and Religious Exclusivism . . . . . . . . . . . . . . . 19

Summarizing Religious Exclusivism . . . . . . . . . . . . 22

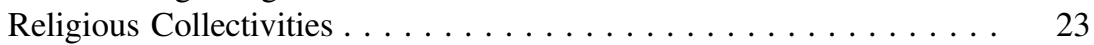

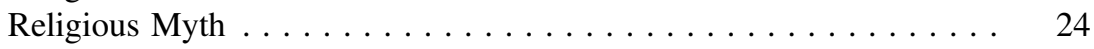

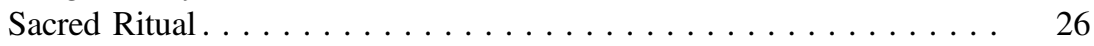

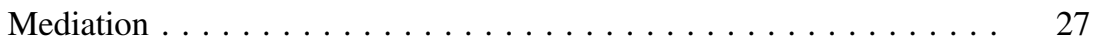

The Mediatorial System . . . . . . . . . . . . . . 28 
Part II The Sacred Story(ies) of the Abrahamic Religions from Three Vantage Points

3 The Story from the Vantage Point of Judaism . . . . . . . . . . . . . 37

Introduction. . . . . . . . . . . . . . . . . . . 37

The Abraham Story Within Judaism . . . . . . . . . . . . . . . . . . . . . . . . . . . . . . . . . .

Dating the Jewish Story . . . . . . . . . . . . . . . . . . . 42

Unpacking the Meaning of the Story .............. 43

The Hasmoneans . . . . . . . . . . . . . . . . . . . . 45

Synchronic Meaning of the Story . . . . . . . . . . . . . . . . . . . . . . 47

Isaac in the Jewish Story. . . . . . . . . . . . . . . . . . . . 49

4 The Story from the Vantage Point of Christianity . . . . . . . . 53

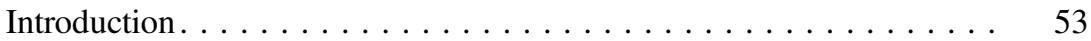

The Jewish Story in the Book of Hebrews and the Letter of James. . 53

The Jewish Story in the Synoptic Gospels . . . . . . . . . . . . . 55

An Extended Version of the Aqedah? ............... 56

Later Christian Writing . . . . . . . . . . . . . . . . . . . . 59

The Growth of the Story .................. 61

5 The Story from the Vantage Point of Islam . . . . . . . . . . . . . . 63

Introduction. . . . . . . . . . . . . . . . . . 63

Ibrahim and Ishaq in the Islamic Story and Ritual . . . . . . . . . . . . . . . 64

Ishaq and Ishma'il in the Islamic Version . . . . . . . . . . . . . . . 65

Biblical Truth or Jewish-Christian Colonizing?. . . . . . . . . . . 67

The Islamic Account: Re-Interpretation or Original? . . . . . . . . . . . . . 69

The Qur'an and the Overwhelming Basis of Submission. . . . . . . . 72

\section{Part III Islamic and Islamist Scholarship and the Abrahamic (Ibrahimic) Tradition}

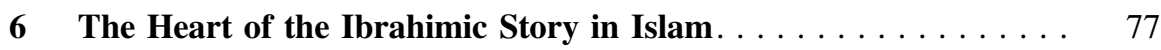

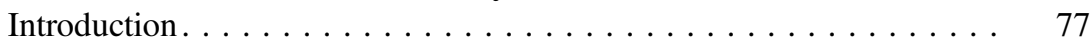

Ibrahim, Ishma'il and the Distinctiveness of Islam . . . . . . . . . . . 78

The Importance of Ibrahim and Ishma'il to Islam . . . . . . . . . . . . . . . . . . . . . . . 80

The Centrality of Ishma'il . . . . . . . . . . . . . . . 81

Further Reflection on the Abraham/Ibrahim Story. . . . . . . . . . 82

Positioning Abraham and His Progeny in the Jewish Account . . . . . 84

An Arabic Account of Ibrahim and His Progeny . . . . . . . . . . 85

Moses/Musa . . . . . . . . . . . . . . . . . . . 88

The Need for and Justification of Islam. . . . . . . . . . . . . . . . . 90 
7 The Increasing Cogency of Islamism . . . . . . . . . . . . . . . 93

Introduction. . . . . . . . . . . . . . . . . . 93

Islamic Reinterpretation of the Past. . . . . . . . . . . . . . . 93

Islamist Radicalism. . . . . . . . . . . . . . . . . . . . . . . . . . . 95

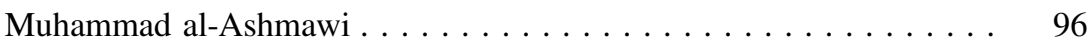

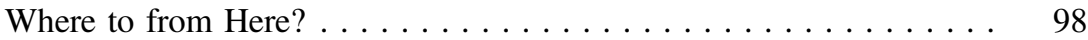

\section{Part IV Exploring Convivencia and the Potential} for Islamic Leadership

8 The Historical Exemplar: La Convivencia . . . . . . . . . . . . . . 103

Introduction. . . . . . . . . . . . . . . . . . . . . . . . . . . . 103

Convivencia and the Earlier Theory of Religion . . . . . . . . . . 103

The Caliphate of Cordoba . . . . . . . . . . . . . . . . . . . 105

Norman Palermo . . . . . . . . . . . . . . . . . . . . 108

Christian Toledo . . . . . . . . . . . . . . . . . . . . . . . . . . 110

Convivencia in the North of Spain . . . . . . . . . . . . . . . . . . . . . . 112

Summarizing Convivencia . . . . . . . . . . . . . . . . . 114

Dismantling the Umbrella and Destroying Convivencia . . . . . . . . 115

9 Re-constructing Convivencia in the Twenty-First Century . . . . . . . 119

Introduction. . . . . . . . . . . . . . . . . . . . . . . . . . . . 119

Abrahamic Harmony and Islam's Special Role. . . . . . . . . . . . . . 119

Releasing the Exclusivist Trigger . . . . . . . . . . . . . . 122

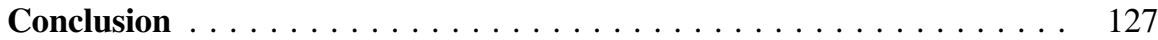

References. . . . . . . . . . . . . . . . . . . . . . . . . . . . . . . 129

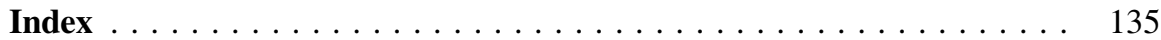

